AÜifDXIV(2005), sonl, s. 21-42

\title{
el-Buharî’nin Kader Konusunda Mu'tezile ile Münakaşaları
}

H. MUSA BAĞCI

YRD. DOC.. DR., DICLE Ü. ILAHIYAT FAKÜLTESI

\begin{abstract}
el-Bukhari's discussions on Qadar With Mu'tazila. While writing his monumental work "al-Jami' al-Sahih", al-Bukhari was influenced by religious and cultural discussion / currents and by discussions on belief of his time. He wrote some parts in his book as a reaction / response to groups of bid'a (innovative sects). One of the parts is Kitap al-Qadar (Book of Destiny), was written against Mu'tazila to criticize their interpretation of Qadar. This fact is seen in the Sharhs (Elucidations) of the elucidators who interpreted hadiths of the book.
\end{abstract}

key words

Al-Bukhari, Kitab al-Qadar, Mu'tazila, Innovate Sect (The Group of Bid'a).

Bu makalede el-Buharî (256/870)'nin el-Câmi'u-s-Sahîh adlı eserinin Kitâbu'l-Kader bölümünün tetkiki ve Ehli Hadis'i temsil eden el-Buharî ile başlangıçta Kaderiyye, daha sonra Mu'tezile olarak tarih sahnesine çıan fırka ile kader konusundaki münakaşalarını irdelemek istiyoruz. Bu tartışmada el-Buharî'nin Kitâbu'l-Kader bölümü temel hareket noktası olacaktır. Zira her ne kadar bizzat el-Buharî Kitâbu'l-Kader bölümünü Mu'tezile'ye bir reddiye olarak oluşturduğunu açıkça ifade etmese de gerek kullandığı bab başlıkları gerekse kader kitabında tasnif ettiği hadisler, kaderi telkin etmesi ve doğrudan kaderin ispatına yönelik olması nedeniyle, onun Mu'tezile'ye karşı yazılan bir reddiye olduğu kuvvetle muhtemeldir. Ayrıca Kitâbu'l-Kader'in içinde kullanılan ayetler ve bu ayetlerin yorumuna ilişkin görüşler, hep kaderi ispatlamaya matuftur.

el-Buharînnin kader ile ilgili görüşlerini bab başlıklarından, bu başlıklardaki yorumlarından ve müteakiben tasnif ettiği hadislerden tespit etmeye 
çalışacağız. Ayrıca el-Buhârî̀nin el-Câmiu's-Sahîh'i hakkında yazılan şerhler, onun kaderle ilgili görüşleri hakkında fikir vermeleri bakımından bizce önemlidir. Bu şerhler, 'el-Buharînnin hangi bab başlıklarını ve bu babların yorumuyla ilgili ifadeléri ve hangi hadisleri Mu'tezile'nin reddi mahiyetinde getirdiğine ışık tutácak niteliktedir. Dolayısıyla şerhlerin el-Buharînnin düşüncelerini anlamańlız açısından büyük önemi olduğu açıktır.

Bizim bu tartışmada amacımız azamî derecede objektif davranarak her iki tarafın delillerini ortaya koymak ve görüşlerini olduğu gibi yansıtmaktır. Ayrıca el-Buharî̀nin es-Sahîh'ini ve özellikle konumuzun mihverini teşkil eden Kitabu'l-Kader'i hangi amaçla, kimlere karşı ve hangi sosyal ve kültürel ortamda yazdığını ortaya çıarmaktır. Bu tartışmalar esnasında el-Buharînnin kader konusundaki görüşleri de tetkik edilmiş olacaktır.

\section{el-Buharî́nin Kitabu'l-Kader Bölümünü Yazmasının Amacı}

Hiç bir eser, içinde bullunduğu çağın siyasî, sosyal, tarihî, dînî ve kültürel yapısından soyutlanamaz. Gerek el-Buharî'nin es-Sahîh'i gerekse diğer hadis külliyatı, söz konusu edilen ortamlardan azade meydana getirilmiş değildir. Ehli Hadis tarafíndan yazılmış hadis külliyâtının telif amaçlarından biri de kendileri açısından tehlikeli bir şekilde gelişme gösteren bid'atları yok etmek, yok olma tehlikesiyle karşı karşıya olan sünneti ihya etmek ve sünnetin önünde eng'el olan firka mensuplarmın görüşlerini bertaraf etmektir. Nitekim İbn Hacer, Tabiîn asrının sonlarında âsârın tedvini ve haberlerin konularına göre tasnif edilmesinin nedenini, alimlerin çeşitli şehirlere dağılması ve Ḧaricîler, Rafızîler ve kader münkirlerinin (Mu'tezile) bid'atlarının çoğalmașı̣lyla açıklamaktadır. ${ }^{1}$ Bir anlamda İbn Hacer, hadislerin tedvin ve tasnifini çoğalan bid'at tehlikesine karşı bir tedbir olarak kabul etmektedir. Bu doğru bir tespittir. Söz konusu hadis mecmualarının bölümleri ve onların ált başlıkları (bab başhkları) müellifinin konuyla ilgili görüşlerini yansıtacakł niteliktedir. el-Buharî de el-Câmiu's-Sahîh adlı eserini oluştururken yaşaç่ı̆ı̆ asrın söz konusu dinî ve kültürel yapısından ve o dönemdeki itikadî tartışmalardan etkilenmiştir. Onun eseri bu atmosfer içinde şekillenmiştir. O, es-Sahîh'inin bazı bölümmlerini bid'atçı firkalara reddiye mahiyetinde oluşturmaya çalışmıştır. İbn Hacer $(852 / 1448)$ 'in yorumuna göre el-Buharî! Kitabu't-Tevhîd'i Kaderiyye ve Cehmiyye'ye, Kitabu'lFiten'i Haricîler'e, Kitabu'l-Ahkâm'ı da Rafızîlere reddiye olarak yazmıştır. ${ }^{2}$

1 Ibn Hacer. Hedyu's-sârî (Mukaddime), Daru'l-Ma'rife , Beyrut, Tarihsiz, I, 6.

2 Ibn Hacer, Fethu'l-bârî, XIII, 290; el-Kastallânî, İşẩdu's-sârî, X, 344; M. Hayri Kurbaşoğlu, Ashâbu'l-Hadis'in Akaid|Edebiyatı, İslânî Arş. Der, Sayı: 5, Ekim, 1987, s. 80 ; Kamil Çakın, Buharînin Murcie ile İman Konusunda Tartışmast, AÜiF der. Ankara, 1992, XXXII, 184. 
el-Buharî, Kitabu'l-İman'ı ise Murcie'ye reddiye mahiyetinde kaleme almıştır. $^{3}$ el-Buharî̀nin reddiye yazdığı bu dört fırka, yani Kaderiyye, Cehmiyye, Haricîler ve Rafizîler bid'at firkalarının başını çekmektedirler. ${ }^{4}$

Şârihlerin yorumlarına bakılacak olursa el-Buharînin, eserindeki Kitâbu'l-Kader bölümünü kaderi reddeden Mu'tezile firkasına bir reddiye olarak yazmış olması kuvvetle muhtemeldir. Çünkü bu bölümün bab başlıkları, bu başlıklar içerisinde kullandığı hadisler, hatta bab başlıkları içerinde serpiştirdiği ayetler ve bu ayetlerin izahı mahiyetinde yapmış olduğu açıklamalar bunu açıkça göstermektedir. el-Buhârî'deki kader bölümü on altı babtan oluşmaktadır. ${ }^{5}$ el-Buharî, on altı babın başhı̆ı̆ını ayetlerden, hadislerden ve fikhî mahiyetteki ibarelerden oluşturmuştur. $O$, kadere iman ile ilgili hadislere de Kitabu'l-İman bölümünde yer vermiştir. Bu yüzden "elBuharî'nin fikhî görüşleri bab başlıklarındadır" sözü meşhur olmuştur. elBuharî'nin bu özelliği nedeniyle onun kaderle ilgili görüşlerini bab başlıklarından, burada kullandığı ayetlerden, hadislerden ve bunlarla ilgili yaptı$\breve{g}_{1}$ yorumlardan öğrenmek mümkündür.

Yukarıda da belirttiğimiz gibi İbn Hacer, el-Buharî'deki bazı bölümlerin bazı fırkalara reddiye olduğunu belirttiği halde, kader bölümünün Kaderiyye'ye reddiye olmasından bahsetmemektedir. Oysaki İn Hacer'in de içinde bulunduğu el-Buhârî şârihleri, kader bölümünü şerh ederken bazı bab ve hadislerin Kaderiyye'ye bir reddiye oldukların ifade etmektedirler ve Kaderiyye'nin görüşlerini eleştirmektedirler. Örneğin, el-Aynî (855/1451) kader bölümünün 5. babındaki "Ameller sonlarına göredir," hadisinin, "İnsan kendi işinin malikidir, hayrı ve şerri seçmekte muhtardır," diyen Kaderiyye'ye karşı kesin bir hüccet olduğunu ifade etmektedir. " Yine o, 13. babta Felak sûresinin 1. ve 2 . ayetlerini delil olarak getiren el-Buharînin kulun kendi fiilini yarattığını iddia eden kimselere (Kaderiyye) bu ayetin bir reddiye olduğunu belirtmektedir. ${ }^{7}$ el-Kastallânî $(923 / 1517)$ ise Felak sûresinin ilk ayetlerinin Allah'ın her şeyi yarattığına delalet ettiğini, bu sûrede kulun fiilini yarattığını iddia edenlere (Kaderiyye) bir reddiye olduğunu ifade etmektedir. ${ }^{8}$ İbn Hacer de el-Buharînnin Felak sûresinin ilk ayetini

3 Bu konuda yapılan bir araştırma için bkz: Kamil Çakın, Buharînin Murcie ile İman Konusunda Tartışması, AÜIF. Der. Ankara, 1992, XXXII.

4

5 el-Buharî, 82 Kader 1, (VII, 210).

- el-Aynî, Umdetu'l-kârî şerhu sahîhi'l-Buhârî, Idaretu't-Tıba'ati'l-Muniriyye, Mısır, Tarihsiz, XI, 153.

7 el-Aynî, a.g.e, $\mathrm{XI}, 160$.

¿ el-Kastallânî, Irşấdu's-sârî li şerhi sahîhi'l-Buharî, el-natba'tu'l-Meymene, Mısır, 1306, IX, 343. 
Kaderiyye'ye reddiye mahiyetinde getirdiğini ifade etmektedir. ${ }^{9}$ el-Aynî, 16. babta geçen hadisin Allah'n hidayeti ve dalâleti yaratmada tek olduğunu, kullara iman ve küfürden murad ettiği şeyin iktisabını takdir ettiğini ve Kaderiyye'nin iddia ettiği gibi bunun kulların fiillerinin yaratıcısı olmadığına bir nas olduğunu açiklamaktadır. ${ }^{10}$ el-Kastallânî, 16. babtaki hadisi yorumlarken şöyle demektedir: Ehli Sünnet mezhebinin görüşü şudur: Allah kullarına iman ve küfǘrden murad ettiğini kazandırmaya muktedirdir. Bu Kaderiyye'nin iddia ettiği gibi kulların fiillerini yaratması şeklinde değildir. " el-Kastallânî, bulbabta geçen A'raf sûresinin 43. ayetiyle ilgili Mu'tezile mezhebinin insanın hidayeti konusundaki görüşünü zikretmekte ve bunun tutarlı olmadığı́nı ifade ederek eleştirmektedir. ${ }^{12}$ Ibn Hacer, 4. babtaki hadislerde verilen $\mid$ anlayışın, her ne kadar kendilerinden sadır olsa da kulların fiillerinin Allah'ın ilminde sabık olup onun takdiriyle vuku bulduğunu ifade etmekte vé bu hadislerin Kaderiyye'nin görüşünün sarih olarak batıllığına delalet ettiğ́ini belirtmektedir. ${ }^{13}$ Yine İbn Hacer, 9. babtaki Ebu Hureyre hadisiyle ilgili İbn Battal'n yorumunu verdikten sonra "Böylece Kaderiyye ve Cebriye'nin görüşü reddedilir" demektedir. ${ }^{14}$ Son olarak İbn Hacer, Hz.Adem ile Hz.Musa'nın tartışması hadisinin son kısmını Hz.Peygamber'in "Adem Musa'ya galebe çaldı" ifadesiyle bitirdiğini ve onun kaderi inkar eden Mu'tezile gibi ümmetinin bir kısmını uyarmak amacıyla yaptığını açıklamaktadır. ${ }^{15}$ el-Buharî̀nin bab başlıklarında kullandığı ayetler ve sahabeye ait görüşler ve onun bunları izah mahiyetindeki yorumlarıyla birlikte şârihlerin naklettiğimiz yorumları, el-Buhârînin kader kitabını Kaderiyye'ye karşı yazdığının bir göstergesi olarak kabul edilebilir.

el-Buharî́nin Mu'tezilî Çevre ile Münasebeti

el-Buharînnin gerek el-Camiu's-Sahîh'inde Kitabu't-Tevhîd (Kitabu't-Tevhîd ve'r-Red ale'l-Cehmiyye ve ğayrihim), Kitabu'l-Kader, Kitabu'l-Fiten, Kitabu'l-İman gibi bölümlerinde ve gerekse bir diğer eseri olan "Halku Efâli'lİbad"da ele aldığı koṇulardan anlaşıldığına göre, o, itikadî meselelerle yakundan ilgilenerek, selef inancına aykırı görüşler ileri süren Cehmiyye, Mu'tezile, Havâric ve Şî mezheplerini tenkit eden ve böylece Ehli Sünnet mez-

12 el-Kastallàni, a.g.e, IX, 345

13 Ibn Hacer, a.g.e, XI, 498

14 Ibn Hacer, a.g.e, XI, 504.

15 Ibn Hacer, a.g.e, XI, 513. 
hebinin oluşumuna katkıda bulunan Sünnî alimlerdendir. ${ }^{16}$ el-Buharî, özellikle Ehli Hadis-Ehli Rey mücadelesinde, Ehli Hadis kanadında yer almayı tercih etmiştir. O, Ehli Rey'i temsil eden Ebu Hanife ve ashabına eleştiriler yöneltmiş ve bazı konularda onlardan farklı düşündügüüü belirtmiştir. ${ }^{17}$ el-Buharî, Hanefilerden Bilhassa iman-amel münasebeti konusunda imanın söz ve amel olduğunu belirterek onlara karşı tavır almıştır. Onun yaşadığı dönemde Kur'an'ın mahluk olduğu (halku'l-kur'an) ve kader meseleleri de yoğun olarak tartışılan konular arasındadır. el-Buharî̀nin yaşadığı muhitteki Kelâmî tartışmalara baktığımız zaman pek çok fırka ve mezhebin bulunduğu görülmektedir. Onun asıl memleketi Buhârâ olmakla birlikte Belh, Bağdat, Nisabur, Mekke, Basra, Kûfe, Şam, Askalân, Mısır, Cezîre, Hıms ve Dımaşk gibi ilim merkezlerine hadis toplamak için uğradığı ve bazılarında uzun zaman kaldığı bilinmektedir. ${ }^{18}$ el-Buharî 6 sene Hicaz'da, 5 sene de Basra'da kalmıştır. ${ }^{19}$ Onun 5 yıl Basra'da kalmış olması, Kaderî/ Mu'tezilî çevre ile münasebeti açısından önemlidir. Bilindiği gibi Basra kurulduğu günden itibaren hep problemli olmuş, siyasî ayaklanmalara merkez teşkil etmiş, kelâmî ekollere odaklık etmiş ve hepsinden önemlisi rivayetlere septik anlayışla bakan Mu'tezile mezhebinin önemli bir merkezi olmuştur. ${ }^{20}$ Başka bir deyişle burası hem bilimsel ve felsefi okulların hem de çeşitli dinsel yönelişlerin tartışıldığı bir yer idi. Burada Kur'an'ın mahluk olup olmadığı, amel-iman münasebeti ve Allah'ın kudreti karşısında insanın özgürlük alanının bulunup bulunmadığı (kader, ihtiyar ve cebr) gibi itikadî sorunlar yoğun bir biçimde tartışılmıştır. ${ }^{21}$ el-Buharînnin yaşadı̆̆̆ dönemin önemli bir meselesi olan Kur'an'ın yaratılması (halku'l-Kur'an) meselesi Mu'tezile ile Ashabu'l-Hadis arasında önemli tartışma konularından biridir. Bu meselenin el-Buharîyle alakalı kısmına değinmekte fayda vardır. el-Hakim Ebu Abdillah şöyle diyor: el-Buharî 250 yılında Nisabur'a geldi. Halk hadis dinlemek için akın akın yanına gidiyordu. Bir gün adamın birisi kendisine Kur'an'ın lafız olup olmadığını sordu. el-Buharî şu cevabı verdi: "Fiillerimiz mahluktur, lafizlarımız da fiillerimizin bir parçasıdır." Onun

16 Yusuf Şevki Yavuz, Buharî mad (Akaide Dair Görüşleri), DİA, (İst, 1992) VI, 372

17 Bu konuda detaylı bilgi için bkz: M. Hilmi Mertürkmen, Buharînin Ebu Hanife'ye Itirazları ve Aralarmdaki İhtlaflar (Basilmamıs Doktora Tezi), Erzurum, 1976.

18 ez-Zehebî, Siyeru a'lami'n-nubelâ, Beyrut, 1990, XII, 394; Krş: Hasan Kurt, Orta Asya'nın İslâmlaşma Süreci (Buhara Ömeği), Fecir yay, Ankara, 1998, s. 304 ; Kasım Kufralı, Buharî mad, MEB. IA, Ist, 1986, II, 771; Talat Koçyiğit, Hadis Tarihi, s. 251.

19 Kufrah, Buhari mad, II, 771.

20 M. Emin Özaf̧̧ar, "Polemik Türü Rivayetlerin Gerçek Mahiyeti”, İslâmiyat I (1998) sayı 3, s. 32.

21 Claude Cahen, Doğuşundan Osmanlı Devletinin Kuruluşuna Kadar Islâmiyet, Bilgi yay, İst. 1990, s. 80. 
bu sözü büyük ihtilafa yol açtı. Çok geçmeden Muhammed b. Yahya ezZuhlî halkı onun aleyhine kışkırtarak: "Bunu kim söylerse bid'atçidir. Onun ne meclisine oturulur, ne de kendisiyle konuşulur." Halk el-Buharînin meclisine gidenleri bid'atçllıkla itham etmiştir. el-Buharînin meclisine kendisiyle aynı görüşü payląşan Muslim b. Haccac ve Ahmed b. Seleme dışında kimse gelmemiştir. Bir defasında Muhammed İbn Yahya, Muslim'e hitap ederek: "Dikkat ediniźz! Kur'an'ın yaratılmıs olduğunu söyleyen, meclisimizde oturmasın!" demiş, Bunun üzerine Muslim ridasını sarığının üzerine kaldırmış ve ayağa kalkarak ondan (İbn Yahya) yazdığı her şeyi kendisine göndermiştir. el-Buharî hayatının tehlikeye düşmesinden endişelenerek Nisabur'dan ayrılmışıı'ır. ${ }^{22}$

Görüldüğü gibi bu'olay, o dönemde halku'l-Kur'an, kader, ihtiyar, cebir gibi konuların nasıl yŏğun bir şekilde tartışıldığını açık bir biçimde göstermektedir. Az önce de belirttiğimiz gibi Basra şehrinde pek çok Mu'tezilî alim yaşamış olup orásı i'tizalin merkezi durumundadır. Vasıl b. Ata (131/ 748) Basra'da tahsilin'i gerçekleştirmiştir. O burada Cehm b. Safvan (128/ 746), Beşsar b. Burd ve Amr b. Ubeyd ile tanışıştır ve Amr'ın kız kardeşyle evlenmiştir. ${ }^{23}$ A'mr b. Ubeyd (145/162), İbrahim en-Nazzam (220/ 835) Ebu'l-Huzeyl el'-Allaf (226/840) da Basra'da uzun süre ikâmet eden Mu'tezilî imamlardan'dır. ${ }^{24}$ el-Buharînin eserinin Fiten bölümü 10. babın ilk hadisinin senedinde "an raculin lem yusemmihi" şeklinde bir ravi müphem olarak zikredilmiştir. Bu müphemlik senedde bulunan Hammad b. Zeyd'den kaynaklanmaktadır. el-Buharî de bu müphem kişiyi tanıması kuvvetle muhtemel olmákla beraber onun kimliği konusunda her hangi bir açıklamada bulunmạmıştır. İbn Hacer'in yorumuna göre ismi tesmiye edilmeyen kişi Mu'tezile'nin şeyhi ve kötü bir zabta sahip olan Amr b. Ubeyd' dir. Muğaltay b. Kılıç el-Bekcerî $(762 / 1361)^{25}$ bu şahsın Hişam b. Hassan olduğunu söylese de|ibn Hacer'e göre bu uzak bir ihtimaldir. ${ }^{26}$ el-Buharî̉ nin bu şahsın Amr b. Ubeyd olduğunu bildiğinden kuşku yoktur. eş-Şafî̀ hadislere olumsuz bákkan ve kendisiyle bu konuda tartışmaya giren kişinin ismini veya mensubú olduğu fırkayı belirtmediği gibi el-Buharî de Mu'tezile mezhebine mensup olması nedeniyle onun ismini açıkça zikrederek ona

22 ibn Hacer, Fethu'l-bâri, II, 203-204.

23 Neşet C.ağatay, Vastl b. Ata mad. MEB. I.A, XIII, 219.

24 Bu konuda geniş bilgi için bkz: Osman Aydınl, İslâm Düşüncesinde Aklîleş̧me Süreci, Ankara Okulu, Ankara, 2001, s! 93-132; Basra'da yaşayan alimler için bkz: W. Montgomery Wath, islâm Düsüncesinin Teşekkül Devri, (Çev: Ethem Ruhi Fığlalı) Umran yay, Ankara, 1981, s. 131-138

25 Hayruddin ez-Ziriklì, ei-A'lam, Daru'l-ilm, Beyrut, 1992, VII, 275.

wo ibn Hacer, a.g.e, XIII, 32. 
bir değer atfetmekten kaçınmış olabilir. Aslında bu durum el-Buharî̀nin Mu'tezile'ye karşı tavrını ortaya koymaktadır. Netice itibariyle gerek el-Buharî̀nin 5 yıl Basra'da kalmış olması, gerekse onun Mu'tezilî çevre ile direk münasebeti, onun Mu'tezile'nin görüşlerini değerlendirme ve eleştirme imkanını bulmasına fırsat vermiştir. O, gerek Basra'da Mu'tezile ile gerekse gezdiği diğer ilim merkezlerinde Rafizîler, Murcie, Cehmiyye, Haricîler ve Şiâ gibi bid'atçı olarak kabul ettiği bir çok fırkalarla karşılaşma ve temas imkanı bulmuştur. İşte el-Buharî bu yoğun tartışmalar içerisinde el-Camiu'sSahîh adlı esrini 16 yıl süre zarfında yukarıda isimlerini belirttiğimiz şehirleri dolaşarak ve özellikle Basra'da ve diğer şehirlerde çeşitli fırkaların yoğun tartışma atmosferi içinde ilmi seyahatleri neticesinde oluşturmuştur. ${ }^{27}$

\section{Mu'tezile'nin Kader Anlayışı}

el-Buharî'nin Mu'tezile ile kelâmî alandaki tartışmasına geçmeden önce Mu'tezile'nin kader konusundaki anlayışına kısaca temas etmek faydalı olacaktır. Kader meselesi konusunda ilk defa görüş beyan eden kişi Ma'bed b. Halid el-Cuhenî (80/699)'dir. O, el-Hasen el-Basrî (110/728)'nin meclisine devam edenlerdendi. Basra'da bu görüşü yaymaya başladığı zaman Amr b. Ubeyd (145/762) de ona katılmış, Basra halkı da onun peşinden gitmiştir. ${ }^{28}$ Muslim'in es-Sahîh'inde de Basra'da kaderin nefyi konusunda ilk konuşan kimsenin Ma'bed el-Cuhenî olduğu nakledilmektedir. Bu rivayete göre başta Ma'bed olmak üzere bu görüşe sahip olan kimseler "kaderin olmad1ğını ve her şeyin yeniden meydana geldiğini" (La kadera enne'l-emra unufun) savunmaktadırlar. ${ }^{29}$ Ma'bed'den sonra aynı görüşleri savunan ve yayan kişi Gaylan ed-Dımaşkî $(101 / 721)^{\prime}$ dir. $^{30}$ Kaderiyye fırkasının bu iki şahsiyetinin kaderin nefyi konusundaki fikirleri, onların takipçileri olan Mu'tezile imamları tarafından benimsenmiş ve sistemli hale getirilmiştir. Mu'tezile mezhebinde kaderin nefyi ve insan iradesinin hürriyeti meselesi adalet prensibi içinde mütalaa edilmiştir. Bu prensibe göre Allah adil olup kullarına asla zulmetmez. İnsan hürdür. İnsan kendi fiilini kendisi yaratır. Allah kullarına bir şeyi yapıp yapmama gücü vermiştir. Eğer insan her hangi bir şeyi yapmak hürriyetine sahip değilse, o insanın işlediği kötü veya iyi amellerden dolayı ceza veya sevap görmesi manasız olur. Eğer Allah belirli

27 Muhammed Ebu Zehv, el-Hadîs ve'l-muhaddisûn, Daru'l-Fikri'l-Arabî, Mısır, Tarihsiz, s. 378.

28 Takiyıddin Ahmed el-Makrizî, Kitabu'l-hutat vel-âsâr, Mısır, 1324, IV, 181.

29 Muslim, 1 Iman 1 Hn: 1 (I, 36-7).

3) Erken Isslâmî dönemdeki ilk tartışmalar için bkz: Illhami Güler. Allah'ın Ahlâkîliği Sorunu, Ankara Okulu yay, Ankara, 1998, s. 78-81; H. Musa Bağcı, Kader İnancının Siyasetle ilişkisi ve Bu Iliskinin Hadis Uydurmadaki Rolü, DüiF der. Diyarbakır, 2000, II, 105-131. 
fiilleri yapmaya zorlamış farz edilirse, Allah'ın o fiillerden dolayı bir insanı cezalandırması zulüm olur. Allah'ın mutlak adaletinin gerçekleşmesi için insan hiçbir tesir altında kalmadan kendi fiilini kendisi yapmalıdır. İrade hürriyeti olmayan bir| insanın sorumlu tutulması, Allah'ın adaletiyle bağdaşmaz. ${ }^{31}$ Mu'tezile bu düşünceyi destekleyen bir çok ayeti delil olarak getirmektedir. $^{32}$

Mu'tezile'nin ortaya koyduğu bu düşünce, Ehli Sünneti temsil eden elEş'arî (324/942) ve el-Maturidî (333/944) tarafından şiddetle tenkit edilmiş ve bu mezhep Hz.Peygamber'e isnad edilen "Kaderiyye bu ümmetin Mecusîleridir" ${ }^{33}$ sözüylle zemmedilmiştir. ${ }^{34}$ el-Eş'arî fiillerin yaratıcısının Allah olduğunu, insanın da bu yaratılmış fiilleri kesbettiğini savunmuştur. ${ }^{35}$ el-Maturidî ise Allah'in küllî iradesini kabul etmiş ve kesbin kulun bir şeye niyet ve azmetmesi ile hasıl olacağını savunmuştur. ${ }^{36}$ Bilindiği gibi Ehli Sünnet'in akaid esasları Ehli Hadis/Ashabu'l-Hadis tarafından belirlenmişti. el-Eş'arî ve el-Maturidî, Ehli Hadis çizgisinde hareket etmiş ve bunlar daha önceden Ehli Hadis tarafından oluşturulan akaid esaslarını akıl ile desteklemiş ve Mu'teźile'ye karşı Ehli Sünnet'in akaid esaslarını savunmuşlardır. Burada el-Eş'arî̀ ve el-Maturidî'den daha önce yaşamış ve Ashabu'lHadis'ten kabul edilẹn el-Buharînnin eserinin kader bölümündeki kader anlayışını ve Mu'tezile ile olan münakaşasını irdelemeye geçebiliriz. el-Buharî́nin Kader|Anlayışı ve Mu'tezile ile Münakaşaları Ashabu'l-Hadis'e göre kader, takdir manasına masdar olup, Allah'ın eşyayı yaratmazdan önce eșyanın miktarlarını, ahvalini, icad zamanlarını takdir edip bilmesidir. Sabík olan bu ilmi gereğince de onları icad eder. İman, küfür, hayır, şer, menffaat, zarar gibi bütün durumlar Allah'ın ezelî ilmi ve iradesinden sadır olúr. Bütün bunların hepsi kendisinden başka ilah olmayan ve yaraticı bulunmayan Allah'in kudreti ve tesiriyle hasil olur. Onun

31 Kâdî Abdulcebbâr, Serhu'l-usûlü'l-hamse, Mektebetu Vehbe, Kahire, 1996, s. 301 vd. Ayrica bkz: 336-350; Kemal Iş̧ı, Mu'tezile'nin Doğușu ve Kelâmî Görüşleri, AÜif yay, Ankara, 1967, s. 69; Mir Veliyyuddin, Mu'tezile, İslâm Düşünce Tarihi, Editör: M.M. Şerif, İnsan yay, ist, 1990, Il, 236; Muhammed Ebu Zehra, Tarihu'l-mezahibi'l-islâmiyye, Daru'l-Hadis, 1987, s. 127.

32 4, Nisa , 40; 9, Tevbe, 70; 30, Rum, 9; 10, Yunus 44; 2, Bakara, 281, 286.

33 Ebû Davud 34 Sunne, Kader 17 (IV, 222). Bu hadisin mevzû olduğunu gösteren kaynaklar için bkz: İbnu'l- Cevzî, el-Mevzûat, Daru'l-Fikr, B.y.y., 1983, I, 274 ; eş-Şevkânî, el-Fevaidu'lmecnû́'a, Kahire, 1960', s. 502; es-Suyutî, el-Leâli'l-masnû'a, Daru'l-Kutubi'l-İlmiyye, Beyrut, 1996, I. 133, 134 ; Ibri Arrak, Tenzîhu's-seri'a, Daru'l-Kutubi'l-IImiyye, Beyrut, 1981, s. 316 Ebu'l-Hasen el-Es'arî, el-íbanne an usûli'd-diyâne, Mektebetu Dâru'l-Beyân, 1993, S. 39, 140.

35 el-Eş'ari, Kitabu't-lum'a', s. 69.

36 Ebu Zehra, a.g.e, s. 182. 
mülkünde Onun hüküm ve takdirinden başka hiçbir şey cereyan etmez. ${ }^{37}$ Bu konuda Abdülkerim İbnu's-Sem'ânî (562/1167), Ehli Sünnet'in görüşünü şöyle özetlemektedir: Bu konuyu bilmenin en iyi yolu, akıl ve kıyası devreye sokmaksızın kitap ve sünnete bağlı kalmaktır. Kim kitap ve sünnetten saparsa, o sınırsız sahada hayret ve dalâlete düşer ve kalbi mutmain olmayıp şifa bulamaz. Çünkü kader Allah'ın kendisine tahsis ettiği bir sırdır ki, onun önüne çektiği bir perde ile Allah onu beşerin akıl ve idrakine kapamıştır. Onu Allah bildirmedikçe ne peygamber ne de yakın melekleri bilir. ${ }^{38}$ İbnu's-Sem'ânî̀nin bu ifadeleri, bütün hadisçilerin benimsediği bir görüştür. el-Buharî de kaderi Allah'ın eşyayı yaratmadan önce miktarlarını, ahvalini takdir edip bilmesi ve her şeyin Allah'ın bilgisi çerçevesinde gerçekleşeceği anlamını ifade eden bab başlıkları koymuştur. Kader kitabının 2. bab başlığı olarak o, "Allah'ın ilmi üzere yazan kalem kurudu" ifadesini ve arkasından "Allah onu bir ilim üzere sapittı" (45 Casiye 23) ayetini serdetmiştir. Bunu muteakiben Hz.Peygamber'in Ebu Hureyre'ye "Senin karşılaşacağın mükadderatı yazan kalem kurudu" sözünü ve "leha sâbikûne" (23 Mu'minûn, 61) ayeti için İbn Abbas'ın "Onlar için saadet (Allah'ın ilminde) sabık olmuştur"39 yorumunu nakletmiştir. Bu nakiller el-Buharî̀nin kaderi nasıl yorumladığını açıkça ortaya koymaktadır. Ona göre kalemin kuruması, Allah'in hükmünün değişmemesi demektir. Ashabu'l-Hadis'in yorumuna göre kalemlerin kuruması Allah'ın eşyanın miktarını ilm-i sabıkında takdir buyurması ve levhi mahfuza yazılma işinin tamamlanmasıdır. Yazı yazan kalem kurursa, onunla fazla veya eksik bir şey yazma imkanı kalmaz. ${ }^{40} \mathrm{O}$, bu görüşünü ayetle de destekleyerek ayeti 'ezelde ilmiyle onu sapıttı' manasında serdetmiştir. ${ }^{41}$ el-Buharî, İbn Abbas'ın "onlar hayırda yarışırlar ve onlar onun için önde gidenlerdir" (23 Mu'minûn 61) ayeti hakkındaki "onlar için saadet öne geçmiştir" yorumunu kendi kader anlaylşına bir destek olarak nakilde bulunmuştur. Buna göre hayırda önde gidenlerin önde olmalarının nedeni Allah'ın ilminde ve takdirinde onların saadet üzere olmalarından dolayıdır. ${ }^{42}$ el-Buharînnin bu babta serdettiği hadis de önceden tayin ve tespit anlamında bir kader inancını destekleyecek niteliktedir. İmran b. Husayn'ın rivayetine göre bir adam Hz.Peygamber'e XI, 145; el-Kastallânî, a.g.e, IX, 328.

el-Buharî, 82 Kader 2, (VII, 210).

en-Neveví, a.g.e, XVI, 198.

el-Aynî, a.g.e, XI, 147 ; el-Kastallânî, a.g.e, IX, 331.

el-Kastallânî, a.g.e, IX, 331 ; İbn Hacer, a.g.e, XI, 492. 
Cennet ehli ile Cehennem ehli bilinir mi diye sorduğunda o, evet, diyor. Adam o zaman "öylèyse (ezelde bunlar biliniyorsa) çalışıp amel işleyenler niçin amel ediyorlar? dediğinde, Hz.Peygamber "Herkes ne için yaratılmışsa onun için çalışır, yahut kendisi için kolaylaştırılıp hazırlanan şey için çalışır." demektedir."3 Muslim'de geçen rivayette İmran, Ebu'l-Esved edDuelî̀ye "Ne dersin, insanların bugün yapmakta olduğu ve hakkında çaba gösterdikleri şey, onlara takdir edilmiş ve geçmişte haklarında kaza buyurulmuş bir kader midir? Yoksa geleceklerine ait Peygamberlerinin kendilerine getirdiği ve haklarında hüccet sabit olan bir şey midir? diye sormuştur. O da "Bilakis hakklarında hüküm verilmiş ve geçmiş bir kaderdir" şeklinde cevap vermiştir. İmran, bu zulüm olmaz mı? deyince, o, "Hayır her şeyi Allah yaratmış ve onun mülkündedir. Ona yaptığından sorulamaz" demiştir. Bunu tasdik için de Şems sûresinin 8. ayetini delil olarak getirmiştir. ${ }^{44}$ İbn Hacer bu son rivayetle ilgili olarak Kâdî Iyaz'dan şunu nakletmektedir: "İmran, bu rivayette Ebu'l-Esved'e Kaderiyye'nin şüphesini ihsas ettirmiştir." ${ }^{5}$ Bu hadisten ánlaşıldı̆ğına göre İmran'la Ebu'l-Esved arasında geçen bu diyalog, Kaderiyýe'nin 'İnsan davranışlarının önceden takdir edilmediği ve önceden takdir édilmiş olsaydı bu zulüm olurdu' şeklindeki inancının bir reddiyesidir. Ebư'l-Esved, aynı rivayet içinde bunu Hz.Peygamber'den bir rivayet nakletmék suretiyle reddetmektedir. ${ }^{46}$

Bu diyalog, o dönememde sahabe arasında Kaderiyye'nin görüşlerinin tartışıldığının açık bir kanıtıdır. Bu hadis, kader tartışmalarının hadislere yansımasının bir işaretil olarak kabul edilebilir. Buradan hareketle söz konusu ettiğimiz el-Buharî hadisi (İmran'ın hadisi) de Kaderiyye'nin bir reddi mahiyetindedir. Netice' itibariyle Ehli Sünnete göre Bu hadisler kaderi ispat etmektedir. Vaki olán her şey Allah'ın kazası ve kaderiyledir. O yaptığı şeylerden sorulmaz, Mülk ona aittir, dilediğini yapar ve Malike mülkünde itiraz olmaz. Çünkü Alliah'n fiilleri için bir illet aranmaz. ${ }^{47}$ Dolayısıyla Allah'ın ilminde olan her şey, o bilgi çerçevesinde gerçekleşecektir. Allah'ı ilminde ve takdirinde bir değişme söz konusu olamaz. Mu'tezile de Allah'ın kainatta her şeyi bildiğini|ve zatı ile alim olduğunu ve her şeyi önceden bildiğini kabul etmektedir. Söz konusu bu mezhep ezelî ilimle insan iradesi arasında bir çatışma görmemektedir. ${ }^{48}$ Bu konuda Ehli Sünnet ile Mu'tezile ara-

43 el-Buharî, 82 kader 2, (VIl, 211).

44 Muslim, 46 Kader 1, Hn: 10, (IV, 2041).

45 İbn Hacer, a.g.e, XI, 493.

46 Muslim, 46 Kader 1, Ḣn: 10, (IV, 2041).

47 en-Nevevî, a.g.e, XVI, 196; Ibn Hacer, a.g.e, XI, 493

48 Kâdî Abdulcabbâr, a.g.e, s. 156 vd. 
sında bir fark yoktur. Kanaatimce fark ezeli ilmin insan davranışlarını yönlendirip yönlendirmediğindedir. Mu'tezile ezelî ilmin insan davranışlarına bir etkisinin olmadığına inanmaktadır. Nitekim Amr b. Ubeyd, Allah'ın ilminin zorlayıcı olmadığını, ne zarar ne de fayda vereceğini ifade etmektedir. ${ }^{49}$ Mu'tezile'nin ekseriyeti Allah'in ilmini, insanlarm kendi faaliyetleriyle fiilen yapacakları şeyin bilgisi şeklinde açıklamışlardır. Allah bir kimsenin iman etmeyeceğini bilmekle beraber, yine de o kimseyi inanmaya muktedir kılmıştır. ${ }^{50}$ Görüldüğü gibi Mu'tezile Allah'ın bilgisinin cebir ifade etmediğini söylerken, el-Buharînin de içinde bulunduğu Ehli sünnet ise Allah'ın ilminin her şeyi kuşattığını ve onun takdirinde değişmezlik vasfının bulunduğunu savunmaktadır.

el-Buharî 4. bab unvanını "Allah'ın emri takdir edilmiş bir kaderdir" (33 Ahzab 38) ayetiyle oluşturmuştur. $O$, burada ayette geçen kader kelimesini önceden tayin ve tespit anlamında yorumlamıştır ve bu yorum çerçevesinde bazı hadislere yer vermiştir. Bu hadislere göre hiç bir kadın evlenmek amacıyla bir başka kadının boşanmasını istememelidir. Zira her ikisi için de takdir edilen bir nasibi (kaderi) vardır. Hz.Peygamber can çekişmekte olan bir çocuğun annesine "Allah'ın aldığı ve verdiği her şey kendisine aittir. Her şeyin bir eceli vardır." demiştir. Hz.Peygamber azil yapan sahabilerine "Hakikat şu ki, Allah'ın (takdir edip) yazdığı her bir nefis, muhakkak var olacaktır," demiştir. Bir başka rivayette ise Hz.Peygamber "Sizden her bir kişinin cehennem yahut cennetten oturağı takdir edilip yazılmıştır," deyince, Ashabtan bir adam Allah'ın takdirine dayanmayalım mı? diye sormuştur. O: "Hayır, sizler çalışıp amel edin, herkese ameli kolaylaştırılır," buyurmuştur. Daha sonra Leyl sûresinin "Kim verir ve sakınırsa" ayetini okumuştur. ${ }^{51}$ Şarihler bu babtan amacın bütün mahlukatın Allah'ın kün emriyle yaratıldığını, kulların hareketleri, iradelerinin farklılığı, iyi ve kötü amelleri gibi bunların hepsinin ne bir ziyade ne bir noksan, ne vaktinden önce ne de sonra belli zamanlarla ve vakitlerle mukadder kulınmış (belirlenmiş) olduğunu ifade etmektedirler. ${ }^{52}$ Aynı zamanda bu şârihlere göre hadislerde amelin terkine ve sabık bir kadere dayanmanın nehyine işaret olup, bilakis, şeriatin varid kıldığı teklifler ve amellerin vacip olduğu, bununla birlikte herkes ne için yaratıldı ise amelinin ona göre kolaylaştırılacağı, saadet ehline saadet ehlinin amelinin, şekavet ehline de şekavet ehlinin

\footnotetext{
49 Abdullah b. Hanbel, Kitabu's-sunen, Demmam, 1986, 1, 438.

so Watt, İsiâm Düşüncesi, s. 293.

51 el-Buhari, 82 Kader 4, (VI, 211-2).

52 el-Aynî, a.g.e, XI, 150.
} 
amelinin Allah tarafından kolaylaştırılacağı ifade edilmiştir. ${ }^{53}$ İbn Hacer zikrettiğimiz son hadisin Ehli Sünnet'in kader konusundaki aslını oluşturduğunu ve saadet ve 'sekavetin Allah'ın takdiriyle olduğunu belirtmektedir. Ona göre bu hadiste' Cebriye mezhebine bir reddiye vardır. Çünkü teysir (kolaylaştırma) cebrin zıddıdır. Cebirde ancak mecburiyet vardır. İnsanın teysir yoluyla yaptığı şeylerde zorlama söz konusu değildir. İbn Hacer'e göre bu hadiste Kadèriyye için de bir reddiye vardır. Ona göre Kaderiyye'nin şüphesinden kứtulmanın yolu şudur: Allah bize ameli emretmiştir. Bizim ise amele sarıl'mamız gerekir. Allah'ın takdiri bizim bilgimiz dahilinde değildir. Ameller Aallah'ın meşietinde sabık olan şeye işaret olarak nasbedilmiştir. Kim bundan ayrılırsa dalâlete ve şaşkınlığa düşer. Çünkü kader, Allah'ın bir sırrıdır ki kendisinden başka kimse muttali olamaz. Sonuç olarak bu babtaki hádislerde her ne kadar onlardan sadır olsa da kulların fiilleri Allah'ın ilmin'de sabık olup onun takdiriyle vukua gelmektedirler. Ona göre burada açikça insanın fiilleri konusunda Kaderiyye'nin görüşünün batıllı̆̆ı ortaya çı̀kmaktadır. ${ }^{54}$

el-Buharî ile Kadèriyye arasında geçen tartışmalardan biri de Hz.Musa ile Hz.Adem arasında geçen tartışmayı ihtiva eden hadistir. el-Buharî bu tartışmayı kader bölümünde şöyle vaz' etmektedir: Kader bölümünün 11 . bab başlığı "Allah k'atında Adem ile Musa'nın birbirlerine hüccet getirip çekişmeleri" şeklindedir. O bu bab başlığı altında bir hadise yer vermektedir. Ebu Hureyre'den gelen rivayete göre Adem, Musa ile münakaşa etti. Musa ona: "Ey Adem! ! Sen bizim babamızsın. Sen bizim ayağımızı kaydırıp cennetten çıkardın," dedi. Adem de ona : "Ey Musa! Allah seni kelâmıyla seçkin kuldı ve kudret eliyle senin için yazdı. Allah'ın beni yaratmazdan kırk yıl önce bana takdir ettiği şeyden dolayı beni kunıyor musun?" dedi. Böylece (Hz.Peygamber) "Adem, Musa'ya galebe çald,," buyurdu ve bunu üç defa söyledi. ${ }^{55}$ el-Buharî bu rivayeti kaderi ispat etmek amaciyla serdetmiştir. Rivayete göre Adem ile Musa'nın bu tartışmasında Hz.Adem'in $\mathrm{Hz}$. Musa'ya galebe çaldiğı Hz.Peygamber tarafından üç defa tekrarlanmak suretiyle onaylanmıs olmaktadır. Bundan dolayı bu rivayet Ashabu'l-Hadis ile Mu'tezile arasında müünakaşa konusu yapılmıştır. Burada hadisin güvenirliliği dışında yoğun olarak münakaşa konusu olan husus, "Hacce Adem Musa" cümlesidir. el-Buharî̀nin de içinde bulunduğu Ashabu'l-Hadis -Bunların içinde raviler, şârihler 'de vardır- Adem kelimesini ref mahallinde fail olarak

53 en-Nevevî, a.g.e, XVI, 196.

54 ibn Hacer, a.g.e, XI, 4.98.

55 el-Buharî, 82 Kader 11, (VII, 214). 
kabulde ittifak etmişlerdir. ${ }^{56}$ İbn Hacer, el-Aynî ve el-Kastallânî bunu bazı insanların nasb mahallinde meful olarak okuyup, Musa kelimesini ref mahallinde fail olarak kabul ettiklerini, fakat bu okuyuşun şâz olduğunu belirtmektedirler. ${ }^{57} \mathrm{Bu}$ okuyuşa göre Musa Adem'e galebe çalmış olur. Bu durumda Kaderiyye'nin görüşü daha güçlenmiş olup Hz.Peygamber'in onayladığı görüş de bu olur. Bu şârihlerin şaz okuyuş tarzını benimseyen insanlardan kastının Mu'tezile olduğu bir sonraki satırdan anlaşılmaktadır. Hafız Ebu Bekir b. Hâssa, Mes'ud b. Nâsır es-Siczî’nin Adem kelimesini nasb halinde ve meful kabul ettiğini nakletmektedir. Aynı zaman da Ebu Bekir, Mes'ud b. Nâsır'in kaderî (Kaderi reddeden) bir kimse olduğunu haber vermektedir. ${ }^{58}$ Görüldüğü gibi Kaderiyye'nin bazı imamları kendi anlayışlanı doğrultusunda gramer açısından bazı tahlillere girişerek hadisten kendi lehlerine bazı sonuçlar çıarmaya çalışsalar da Ebu Ali el-Cubbâî (303/ 915) ve diğerleri gibi bazı imamlar da gramatik tahlillere girmeyip hadisi doğrudan tekzip etmişlerdir. Onlara göre bu hadiste verilmeye çalışılan mesaj, Rasullerin getirdiği mesaja aykırıdır. Hz.Peygamber'e dayandırılan bir hadisten önceden tayin ve tespit anlamında insanın davranışlarını selbeden bir inancın çıkarılması mümkün değildir. Bundan Hz.Peygamber'i tenzih etmek gerekir. Aynı şekilde bütün peygamberleri ve onların tabilerini Allah'a ve Rasulüne isyan eden kimseler için kaderi hüccet kılmalarından tenzih etmek gerekir. ${ }^{59}$ Ashabu'l-Hadis ise onlara karşı kendi yorumlarını destekleyecek bazı deliller ileri sürmektedirler. İbn Hacer, el-Aynî ve elHattabî (388/998) gibi şârihler, Adem kelimesinin ittifakla ref mahallinde fail olmasını şöyle delillendirmişlerdir. Ahmed b. Hanbel (241/855)'in İbn Şihab Zuhrî'den o da Ummu Seleme'den, o da Ebu Hureyre'den rivayetine göre (Haccehu Adem) "Adem ona galebe çaldı" şeklinde bir rivayet varid olmuştur. Bu rivayet, onlara göre hadisteki müşkili ortadan kaldırmaktadır. Çünkü onun ravileri hafız imamlardır. İmam Zuhrî ise hafız fakihlerin büyüklerindendir. Onun rivayeti bu konuda itimada şayandır. Bu durumda "haccehu"nun manası "ona hüccetle galebe çaldı" demektir. ${ }^{60}$ Ibn Abdilber, bu hadisin kaderi ispat konusunda Ehli Hak için önemli bir asıl olduğunu ve Allah'ın kulların amellerini takdir ettiğini ve bunların her birinin

56 ibn Hacer, a.g.e, XI, 509; el-Aynî, a.g.e, XI, 159; el-Kastallânî, a.g.e, IX, 341; en-Nevevî, a.g.e, $\mathrm{XV}, 201-202$.

57 Ibn Hacer, a.g.e, XI, 509.; el-Aynî, a.g.e, XI, 159; el-Kastallânî, a.g.e, IX, 341.

58 Ibn Hacer, a.g.e, XI, 509; el-Aynî, a.g.e, XI, 159.

59 Ahmed Ibn Teymiyye, Mecmû'u fetâvâ, (Kader Kitabı) Mektebetu'l-Meârif, Riyad, Tarihsiz, $s$ 304.

60 Ibn Hacer, a.g.e, XI, 509; el-Aynî, a.g.e, XI, 159. 
Allah'ın sabık ilmi çerçevesinde takdir edildiğini ifade etmektedir. O, (Ashabu'l-Hadis'in bu okuyuş biçimiyle) bu hadisin cebriye için bir hüccet olamayacağını da belirtmektedir. ${ }^{61}$ el-Hattabî de bazı insanların kader manasının icbar ve kulun icbarı anlamında olduğunu zannettiklerini, Adem'in Musa'ya galébe çalmasını da bu şekilde yorumladıklarını ve fakat bunun onların vehmettikleri gibi olmadığını açıklamaktadır. ${ }^{62}$ Bu son değerlendirmelerden|sârihlerin bu hadisin Kaderiyye için olduğu kadar Cebriye fırkası için de bir reddiye olduğunu savundukları ortaya çıkmaktadır. Fahreddin er-Rầzî (606/1209) de Mu'tezile'nin bu hadisle ilgili argümanlarının Ehli Sǘnnet tarafından bir çok yönlerden eleştiriye uğradığını nakletmektedir. Birincisi, bu haber (Mu'tezile'nin iddia ettiği gibi Adem kelimesi mansub okúnduğunda ve Musa galebe çaldığında) Musa'nın Adem'i küçük günahla zemmini gerektirir. Bu da Musa'nın cehaletini intaç eder ki bu caiz déğildir. İkincisi, Hz. Musa'nın babasına (Adem) ağır söz söylemesi uygun değildir. Üçüncüsü, Musa'nın, yaratıkların bahtsız olmasının ve cennetten çıkarılmasının Adem'in yüzünden olmayıp bilakis Allah tarafından ólduğunu bilmesidir. Dördüncüsü, bu durumda Adem hüccet olmayan bir şeyle ihticac etmiştir. Çünkü bu hüccet olsaydı, Firavun, Haman ve sair kafirler de onunla ihticac ederlerdi. Bu batıl olunca, bu hüccet de fasit olur. Beşincisi, biz doğru olmadığını beyan etmekle beraber, Hz.Peygamber getirdiği hüccet konusunda Adem'i onaylamıştır. Bu sabit olunca, hadisi şu üç anlamdan birisine hamletmek gerekir: İlki, Hz.Peygamber bu rivayeti Allah'tan veya kendi nefsinden değil, Yahudilerden rivayet etmiştir. Rasul bu hikayeyi zikretmiştir, ancak ravi Hz.Peygamber'in huzurunal girdiği zaman Yahudilerden naklettiğine dair olan sözüne yetişmemiştir. Dolayısıyla Hz.Peygamber'in onu Yahudilerden değil de kendi nefsinden żikrettiğini zannetmiştir. İkincisi, "hacce Adem" deki Adem mansub olarák okunur. Bu durumda anlam "Musa galebe çaldı" olur ve buna göre Ádem'in getirdiği şey hüccet olmadığı gibi bir özür de kabul edilmez. Üçüncüsü, kabul edilen bir yorumdur: Münazaradan murad, ne masiyetten dolayı zemmetmek ne de Allah'ın ilmi ile ondan özür beyan etmektir. Bilakis Musa cennetten çıkmasına sebep olan bu zellenin sebebini sormuştur! Adem de ona: "benim cennetten çlkmam bu zelle sebebiyle değildir. Bilakis cennetten yeryüzüne gönderilmemin sebebi Allah'ın beni yeryüzüne halife olarak tayin etmesidir." cevabını vermiştir.

i) Ibn Hacer, a.g.e, XI, 509

62 el-Hattabî, Meâlimu's-s'inen, Daru'l-Kutubi'l-îlmiyye, Beyrut, 1996, II, 297. 
Sonuç olarak Adem'in hüccetinin kuvvetli olduğu ve Musa'nın da bu konuda mağlup olduğu muhakkaktır. ${ }^{63}$

el-Buharî ile Mu'tezile arasındaki tartışma noktalarının geçtiği bablardan birisi de "Meşakkate ve kazanın kötüsüne ulaşmaktan Allah'a sığınan kimse" şeklindeki 13. babtır. el-Buharî bu babı destekleyen Felak sûresinin "De ki: Yarattı̆̆ı şeylerin şerrinden sabahın Rabbine sı̆̆ınırım." şeklindeki ilk ayetlerini delil olarak getirmiştir. el-Buharî burada Hz.Peygamber'in "Bela şiddetinden, zorluk ve meşakkate erişmekten, kazanın kötüsünden ve düșmanın sevincinden doğacak hüzünden Allah'a sığınınız "64 sözünü nakletmektedir. Buradaki tartışma konusu kötünün, şerrin Allah'a izafe edilip edilemeyeceğidir. Mu'tezile Allah'ın fiillerinin hasen olduğunu, kabih olan fiillerin Allah tarafından yaratılmadığını savunmaktadır. ${ }^{65}$ Dolayısıyla onlar, Allah'ın şerri yaratmayacağı ve onunla hükmetmeyeceği fikrini benimsemişlerdir. Çünkü eğer Allah, şerri yaratsa ve onunla hükmetse, ardindan da kullarına azab etse; bu, Allah'ın kullarına zulmetmesi anlamına gelirdi. Oysa Allah adildir ve kullarına zulüm yapması düşünülemez. Ebu'l-Huzeyl elAllâf (226/840)'a göre hem hayır hem de şer Allah'ın zatındadır. Allah hayrı irade eder ve onu emreder. Çünkü hayır onun zatındadır. Şerri de yasaklar, çünkü şer de zatındadır. ${ }^{66}$ Buna göre Ebu'l-Huzeyl, Allah'ın kötülüğü ve adaletsizliği yapma gücünün olduğunu, fakat onu yapmayacağı tezini savunmaktadır. Allah'ın zulmü ve kötülüğü yapmaması, iyiliğinden ve ilminden dolayıdır. $O$, insanın kötü eylemlerine müsaade eder; eylemlerin işlenmemesine yönelik otoritesini kullanmaz. ${ }^{67}$ Kadî Abdulcebbar (415/ 1024) da Allah'ın zulme kadir olduğunu fakat bunu yaratmadığını savunmaktadır. ${ }^{68}$ Mu'tezile genel anlamda böyle bir görüşe sahip olduğu için elBuharî bu görüşü eleştirmek amacıyla bu babı oluşturmuş ve müteakiben hadisi zikretmiş̧ir. Bu hadis içerisinde zikredilen her şeyin failinin Allah olduğunu tazammun etmektedir. ${ }^{69}$ Dolayısıyla el-Buharîye göre hayrın da şerrin de faili Allah'tır. $O$ halde bu bab başlığı ve müteakiben serdedilen hadis ve özellikle Felak sûresinin ilk ayetleri Kaderiyye'ye red niteliğindedir. Orada el-Buharî Allah'ın şerri de yarattığı fikrini öne çıkarmaktadır.

63 Fahreddin er-Râzî, et-Tefsîru'l-kebîr, Daru'l-Fikr, Beyrut, 1993, I, 54.

64 el-Buharî, 82 Kader 13. (VII, 215).

65 Kâdî Abdulcebbar, Şerhu usûll't-hamse, s. 324.

66 Osman Aydınl, İslâm Düşüncesinde Aklileşme Süreci, Ankara Okulu, Ank, 2001, s. 204 (Kâdî Abdulcabbâr, Fırak ve Tabakatu Mu'tezile, s. 146'dan naklen); Ayrıca eş-Şehristânî, el-Milel ve'n-nihal, Danu'l-Kurubi'l-ilmiyye, Beyrut, 1992, I, 39.

67 Aydinh, a.g.e, s. 204.

is Abdulcebbar, a.g.e, s. 313-323.

6) Ibn Hacer, a.g.e, XI, 513 
Şarihlerin verdiği bilgiye bakılırsa bu ayet, kulun fililini yarattığı görüşünü savunan Kaderiyyje'yi reddetmek amaciyla serdedilmiştir. Çünkü elBuharî̀nin anlayışına göre kendisinden sığınılması istenen bir kötülük, kulun kendisi tarafından' yaratıldıysa o zaman Allah'a sığınmasının bir anlamı olmayacaktır. Zira ançak kendisinden sığınılan şeyi izale etmeye muktedir olan kimseye sığınmak sahih olur. ${ }^{70}$ Bu ayetteki "Min şerri ma halak" ifadesindeki şer, "Şeytanın' şerri, cehennem veya Allah'ın yarattığı her şer sahibinin şerri" anlamlarınà gelmektedir. Bu ifadedeki 'ma' mevsule ma'sıdır ve ait zamiri mahzuftur. Veyahut da masdariyyedir, bu durumda mahluk anlamında halk olup "halkın şerrinden" manasınadır. ${ }^{71}$ Dolayısıyla Bu sûre Allah'ın hayır ve şerden' her şeyin yaratıcısı olduğuna delalet etmektedir. Burada kulun fiilini yarattığını söyleyen Kaderiyye'ye bir reddiye vardır. ${ }^{72}$ Mu'tezile'den Allah'ın' şerri yaratmadığını savunanlar ise bu ayetteki "Min şerri ma halaka" şerri kesralı tenvinle, 'ma halaka'daki ma'yı nefiy ma'sı kabul etmişlerdir. Bư durumda onlara göre anlam "Allah'ın yaratmadığı şerden sana sı̆̆ınırım,; olur. Ashabu'l-Hadis, bunun batıl bir mezhebe mebnî merdud bir okuyuş bịimi olduğunu savunmaktadır. ${ }^{73}$

el-Buharî dalâlet ye hidayet konusunda da Mu'tezileye karşı tavrını 15. ve 16. bablarda ortaýa koymuştur. Onun bu tavrını ortaya koymadan önce Mu'tezile'nin hidayet've dalâlet kavramlarına nasıl baktığını ifade etmemiz gerekir. Mu'tezile'ye 'göre hidayet, Allah'ın doğru yolu beyan ve işaret etmesidir. Bu beyan vè çağnıy kabul eden hidayete erer, kabul etmeyen değil. Allah kafirlere dọgru yolu gösterir, fakat onlar doğru yola girmezler. Dolayısıyla Allah hem mü'minlere hem de kafirlere hidayet etmiştir. Ama kafirler hidayeti terçih etmemişlerdir. Onlara göre Allah'ın saptırmasının anlamı, kulun dalâléti seçmesi ve sapıtması sonucunda sapıklık hükmünü almasıdır. Yani kuluṇ hidayeti ve dalâleti yine kendi irade ihtiyarına bağlı olmaktadır. Onlara g'öre Allah'ın, yarattıklarından bir kimseyi dinden saptırdığını söylemek iminkansızdır. ${ }^{74}$ Fakat el-Buharînnin de içinde bulunduğu Ashabu'l-Hadis veya en geniş anlamıly Ehli Sünnet, hidayetin ve dalâletin Allah tarafından yaratıldığını savunmaktadırlar. ${ }^{75}$ İste el-Buharî kader bölümünün 15 . ve 16 ! bablarını bu konuya ayırmıs ve burada Kaderiyye'ye red mahiyetinde baż deliller ileri sürmüştür. $O$, Tevbe sûresinin "De ki:

70 Ibn Hacer, a.g.e, XI, 513; el-Aynî, a.g.e, XI, 160, el-Kastallânî, a.g.e, IX, 343.

71 el-Kastallânî, a.g.e, IX, 343 .

72 A.y.

73 A.y.

74 el-Eş'arî, Makâlâtu'l-islâmiyyîn, el-mektebetu'l-Asriyye, Beyrut, 1990, I, 324-5.

75 el-Eşarî, a.g.e, I, 325. 
Allah'ın bizim için yazdığından başkası asla bize erişmez" ayetini 15. bab başlığı yapmıştır. Ayette geçen "Bizim için yazdığı" ifadesini "kadâ", yani "Bizim için hayır ve şerden takdir ve hükmettiği şey vardır," şeklinde tefsir etmiştir. Daha sonra Tabiî alimlerden Mucahid b. Cebr Saffat sûresinin 161. ayetindeki "bi fâtinîn" kelimesini "bi mudillîn" şeklinde tefsir etmiştir ki bu durumda ayetin anlamı şöyle olur: Sizler Allah'ın cehenneme gireceğini yazmıs olduğu kimselerden başkasını dalâlete düşürüp saptıramazsınız" Dolayısıyla el-Buharîye göre sapma ve saptırma insanın iradesinde olmayıp Allah'in kudretindedir. Yani insanın saptırmasını da yaratan Allah'tır. el-Buharî A'la sûresinin 3. ayetindeki "kaddera fe hedâ" şeklindeki ifadeyi "Şakâveti ve saadeti takdir eden ve bütün hayvanları da otlaklarına hidayet edip götüren" şeklinde tefsir etmektedir. ${ }^{76}$ Dalâlet konusundaki yaklaşımını 15. babta veren el-Buharî hidayetle ilgili yaklaşımını da 16. babta dile getirmektedir. Bu babın başlığını yine hidayet anlayışını yansı$\tan$ ayetlerle oluşturmuştur. Bu ayetlerden biri, "Eğer Allah bize hidayet etmeseydi, doğru yolu bulamazdık". (A'raf 43) Diğeri de "Ĕger Allah bana hidayet verseydi, herhalde sakunanlardan olurdum," ayetidir. (Zumer, 57) el-Buharî bu bab başlığı altında el-Bera b. Azib'in Hz.Peygamber'den naklettiği şu ifadelere yer vermektedir: Allah'a yemin olsun ki Allah olmasay$\mathrm{d}_{1}$, doğru yolu bulamazdık. Oruç da tutmaz namaz da kılmazdık..." "7 elAynî'nin ifadesine göre bu 16. babta her iki ayet ve nakledilen hadis, Allah'ın hidayeti ve dalâleti yaratmada tek olduğunu ve Allah'ın kullar için iman ve küfürden murad ettiği şeyi iktisabına muktedir olduğunu ve bunun Kaderiyye'nin iddia ettiği gibi kulların yaratmasıyla olmadığını ispat etmektedir. ${ }^{78}$ el-Kastallânî hidayet konusunda Mu'tezile'nin görüşünü zikredip elBuharî'nin 16. babının Mu'tezile'ye reddiye anlamında oluşturulduğunu ifade etmektedir. Onun nakline göre Mu'tezile mezhebi, Allah'ın enbiya ve evliya için hidayet ve irşad nev'inden yaptığı her şeyi, kafirler ve fasıklar için de yaptığını savunmaktadır. Onlara göre mü'min ile kafir arasında haklı ile haksız arasındaki imtiyaz, kişinin çalışması ve ihtiyarına göre hasıl olur. Dolayısıyla kişinin kendisini övmesi gerekir, çünkü imanı kendi çalışmasıyla hasıl etmiştir. Ki o iman da onu cennetin derecelerine ulaştıracak ve cehenneme düşmekten kurtaracaktır. ${ }^{79}$ el-Kastallânî, Mu'tezile'nin bu düşüncesini eleştirerek insan asla kendi nefsini övmeyip sadece Allah'ı övme-

\footnotetext{
76 el-Buharî, 82 Kader 15, (VII, 215).

7 el-Buluarî, 82 Kader 16, (VII, 216).

78 el-Aynî, a.g.e, XI, 163.

7o el-Kastallânî, a.g.e, IX, 345 .
} 
si gerektiğini ve hidayeti verenin yalnızca Allah olduğunu ifade etmektedir. ${ }^{80}$ Yani ona göre hiddayeti kendi çalışmasıyla elde eden insan olmayıp, hidayeti ona veren Allah'tır. İnsanın fiilleri de dahil her şeyi yaratan Allah olduğu gibi hidayeti ve' dalâleti de yaratan Allah'tır. el-Kastallânî, 16. babtaki "Allah bana hidayet etseydi, (her türlü şirk ve küfürden) sakınanlardan olurdum" (Zumer, 57) ayetini yorumlarken şöyle demektedir: Bu ayette sözü edilen kafir, hidayeti Mu'tezile'den daha iyi bilmektedir. Keza tabiîlerine "Allah bize doğru yolu gösterseydi, biz de size doğru yolu gösterirdik" diyen kafirler de hidayeti çok iyi bilmektedirler. Yani diyorlar ki Allah hidayeti bize muvaffakk kılsaydı ve doğru yolu bize gösterseydi, biz de sizi ona çağırırdık. Oysaki bize dalâlet ve azgınlık verildiği için doğru yolu bulmakta muvaffak olamadık. el-Kastallânî kafirlerin bu yanlış anlayışlarını naklettikten sonra Multezile'nin bu konudaki anlayışını şöyle ifade etmektedir: "Bilakis Allah onlara (kafirlere) doğru yolu gösterdi ve başarıyı onlara verdi. Fakat onlar doğru yola gelmediler." Bu cümle Mu'tezile'nin hidayet ve dalâlet konusundaki bakış açısını yansıtmaktadır. Sonuç olarak elKastallanî kafirlerin hídayet konusundaki tavırlarını eleştirdiği gibi, Mu'tezile'nin bu anlayışını da şu sözlerle eleştirmektedir: Ehli Sünnet mezhebine göre Allah iman ve jüüurrden murad ettiği şeyi kulların iktisabına muktedirdir ve Kaderiyye'nin iddia ettiği gibi, bu iman veya küfrün kullar tarafından yaratılması söz konusu olamaz. ${ }^{81}$

el-Buhârînin kade' kitabının ilk babında -ki el-Mustemlî̀nin rivayetine göre bu babın başlığı|"babun fi'l-Kader"dir- naklettiği hadisler Mu'tezile ile münakaşa konusu olan hadislerdir. Bu münakaşa konusu olan hadis, insanın ana karnındaki durumuyla ilgilidir. Süleyman el-A'meş'in, Zeyd b. Vehb'den, o da Abdullah b. Mes'ud'dan rivayet ettiği bu hadise göre Hz.Peygamber şöyle buyurmuştur: "Sizin her biriniz anne karnında kurk günde toplanır. Sonra bir o kadar zaman içinde kan pihtısı (alaka) halini alır. Sonra bir o kadar zaman içinde/bir çiğnem et (mudğa) olur. Sonra Allah bir melek gönderir de bu melek dört kelime ile yani rızkını, ecelini, şakî yahut said olduğunu yazmakla 'emrolunur. Allah'a yemin ederim ki sizlerden biriniz yahut bir adam ateş ehlinin ameliyle amel etmeye devam eder, nihayet kendisiyle cehennem, arasında bir kulaç yahut bir zira'dan başka bir mesafe kalmaz. Kitap onun önüne geçer, cennet ehlinin amelini işler de oraya girer. Bu sefer o adam' cennet ehlinin ameliyle amel etmeye devam eder, nihayet kendisiyle cenn'et arasında bir kulaç yahut bir zira'dan başka bir mesafe kalmaz. Kitap onun 'önüne geçer, cehennem ehlinin amelini işler de oraya

A.y.

(4) el-Kastallânî, a.g.e, IX, 345 . 
girer." Diğer rivayet ise Enes b. Malik'ten gelmekte olup bu rivaytte "Melek Rabbine erkek mi dişi mi olduğu, saîd mi şakî mi olduğunu rızkı ve ecelini sorar ve anasının karnında iken bunlar böylece yazılır,"82 ifadesi vardır.

el-Buharînin bu hadisi kader kitabının başına koyması gerçekten manidardır. Zira Mu'tezile tarafından şiddetle reddedilen hadislerdendir. Kader konusunda üzerinde en çok tartışılan hadislerden biridir. Bu açıdan el-Buharînnin bu hadisleri başa almasının bir anlamı olmalıdır. Fakat el-Buharî'nin bu hadisler için "Babun fi'l-Kader" şeklinde bab başlığı koyduğu anlaşılmaktadır. İbn Hacer, el-Mustemlî'nin rivayetinde bab başlığı olarak "babun fi'l-Kader" ziyadesinin olduğunu, fakat el-Buharînin es-Sahih'ini rivayet edenlerin çoğu için de böyle olduğunu ifade etmektedir. ${ }^{83}$ Mu'tezile'nin bu hadislerin ilkine şiddetli bir tenkit yönelttiğini söylemiştik. Bu tenkidi yönelten Mu'tezilî imamlarından biri Amr b. Ubeyd (145/762)'dir. Başta da söylediğimiz gibi o, Kaderiyye fırkasının önemli simalarından olan Mabed el-Cuhenî'nin hareketine katılanlardan biridir. Onun insanın anne karnındaki durumuyla ilgili naklettiğimiz hadisi eleştirisini burada zikretmek gerekir. O bu hadisi işittiği zaman şöyle eleştirmiştir: "Eğer bu hadisi el-A'meş söylerken işitseydim ona yalancı olduğunu söylerdim. Zeyd b. Vehb söylerken işitseydim cevap vermezdim. Abdullah b. Mes'ud söylerken işitseydim, kabul etmezdim. Peygamber söylerken işitseydim reddederdim. Allah böyle söyleseydi, Ona da derdim ki: Sen bu esas üzere bizden misak almadın." 84 Bu hadis, İbrahim en-Nazzam (220/835)'ın da eleştiri oklarına maruz kalmıştır. O, özellikle bu hadisi rivayet eden Abdullah b. Mes'ud'u şiddetli bir şekilde eleştirmiştir. en-Nazzam İbn Mes'ud'un, Birva'a bnt Vasık'ın rivayet ettiği hadis hakkında : "Bu hususta ben kendi görüşümü söylüyorum. Eğer hata ise benden, doğru ise Allah'tandır." dediğini zikretmiş ve : "Işste bu zan ve şüphe ile hüküm vermenin ta kendisidir. Zan ile şehadet (şahitlik) haram olursa, zan ile hüküm vermek daha büyük bir (haram)dır. Eğer İbn Mes'ud, aklını fetva ile meşgul edeceğine şakî (dalâlette olan) niçin şakî oluyor, saîd (hidayette olan) niçin saîd oluyor? Bunun üzerinde düşünseydi, Allah'a karşı bu kadar çirkin bir şey söylemez, hatası da büyümezdi ve bu da onun için daha iyi olurdu." demiştir. ${ }^{85}$ Bas-

82 el-Buharî, 82 Kader 1, (VII, 210).

83 Ibn Hacer, a.g.e, XI, 477.

34 el-Hatil) el-Bağdâdî, Tarihu Bă̆dat, Mısır, 1349/1931, XII, 172; Mulnammed b. Halife e]Veştânî el-Ubbî, Ikmâlu ikmali'-mu'lim, Daru'l-Kutubi'l-ilmiyye, Beyrut, 1994, IX, 7. Muslim'in şârihi el-Ubbî, Amr b. Ubeyd'in bu sözünün şeksiz şüphesiz küfür olduğunu belirtmektedir. A.g.e, IX, 7.

85 İbn Kuteybe, Hadis Mudafaast (Te'vilu Muhtelifi'l-Hadis), (Çev: M. Hayri Kurbaşoğlu), Kayıhan, Ist, 1989 , s. 88. 
ra'da beş yil kalmı̧ olan el-Buharînnin kendisinden önce yaşamış olan Amr b. Ubeyd'in ve çağdaşı olan en-Nazzam'ın bu eleştirilerinden habersiz olması mümkün değildir. Mu'tezile'nin kader konusundaki görüşlerini $\mathrm{Hz}$. Peygamber'in dilinden geçersiz hale getirecek bir hadisi kader kitabının başına almış olması, onun Mu'tezile'ye açıktan veya ima yollu bir cevabı olarak kabul edilebilir! el-Buharînnin bu hadisleri müdafaa sadedinde kendisinin sarih bir açıklaması mevcut değildir. Fakat o bu hadisi kader kitabının başına almış olmakjla aslında fiilî bir cevap vermiş olmaktadır. el-Buharî ile aynı asırda yaşamı̧ olan İbn Kuteybe (276/889) bu hadisin müdafaası sadedinde Mu'teżile imamlarından en-Nazzam'a uzun bir cevap vermektedir. Buna göre ó, ỉbnu Mes'ud'un bu hadis nedeniyle yalancı olarak itham edilmesine şöyle cevap verir: “ibn Mes'ud'un böyle meşhur ve yüce bir hadis ile Rasulullah'a yalan isnad etmesi nasil caiz olur? Pek çok ashab mevcut olduğu halde niç̧in hiç biri onun bu sözünü inkar etmiyor? Hem ne için ve ne gaye ile Raśulullah'a yalan isnad etsin ki? Bunun ona ne faydası veya zararı olur, ne sultan ve idarecilere yaklaşmasına vesile olur, ne de malı artar. Onun bu trivayetini destekleyen pek çok kimsenin rivayeti varken nasıl olur da yalán söylemiş olur?" İbn Kuteybe, İbn Mes'ud'un hadisini destekleyen diğger rivayetleri ve bu konudaki ayetleri ve hatta gerek Cahiliye'de gerekse İslâmî dönemdeki Arap şairlerin kader konusundaki şiirlerini zikrederek bu hadisisin doğruluğunu kanıtlamaya çalışmaktadır. ${ }^{86}$ Aslnda bu tartı̧̧maları ýapan müellifler el-Buharînnin çağdaşı olmaları ve özellikle Basra çevresindè yaşamı̧ olmaları nedeniyle kader konusundaki tartışmaların üst seviyeḋe yaşandığını göstermektedir. Doğal olarak el-Buhârî bu tartışmalardan etkilenerek es-Sahih'inin kader bölümünü oluşturmuş olmahilır.

el-Buharînnin insanın ana karnındaki durumu ile ilgili bu hadisi kitabına alması, onun, kişinin' doğduğu zaman yiyip içeceği rızk, eceli, ameli, şakî mi sâid mi olacağı ğibi mukadderatının yazılacağı kanaatini benimsemiş olduğunu göstermekitedir. el-Buharî̀ye göre bunlar kaderin var olduğunu gösteren şeylerdir. él-Buharî̉nin de içinde bulunduğu Ehli Sünnet bu hadiste sayllan maddelerin hepsinin önceden Allah'in ilminde sabık olup değişmesinin mümkün' olmadığını savunmaktadır. Hadiste sayılan bu maddeler konusunda Mứtezile ile hiç birinde hem fikir değillerdir. Bizim burada üzerinde durmak istediğimiz husus özellikle ecel konusudur. el-Buharî hadiste belirtilen her insan için bir ecelin tespit edilmiş olmasını benimsemiştir. Bu yüzden şârihler Ehli Sünnet ile Mu'tezile'nin bu konuda farkh

80 ibn Kureybe, a.g.e, s. $98-101$. 
bakış açılarına sahip olduklarını vurgulamaktadırlar. Ehli Sünnet'in anlayışına göre kat'i delillerle takarrur etmiştir ki ecelleri ve rızıkları Allah bilir. Bilmenin hakikati, bilinen şeyi bulunduğu hal üzere anlamaktır. Allah Zeyd'in beş yüz tarihinde öleceğini bildiği zaman, artık onun bu tarihten önce veya sonra ölmesi imkansızdır. Çünkü ilim cehle munkalip olur. Bundan dolayı Allah'ın bildiği ecellerin artıp eksilmesi imkansızdır. Dolayısıyla Ehli Hakk'ın mezhebine göre öldürülen kimse eceliyle ölmüştür. Mu'tezile ise o kimsenin eceliyle ölmediğini ve ecelinin kesildiğini savunmaktadır. ${ }^{87}$ Mu'tezile'nin cumhuru, özellikle Bağdat ekolü ve yine Mu'tezile imamlarından Ebu'lKâsım el-Ka'bî (319/931)'ye göre ecel iki türlüdür. Birisi, katl eceli, diğeri ölüm ecelidir. Mu'tezile'nin cumhuru ve el-Ka'bî, eğer insan öldürülmemiş olsaydı, ölüm eceline kadar yaşayacağını savunmaktadırlar. Dolayısıyla onlara göre kâtil maktulün ecelini kesmiştir. Maktulün tek bir eceli vardır ve öldürme olmasaydı, o da Allah'ın ilminde olan vakitti. Öldürülmeseydi, kesin olarak yaşayacaktı. Aksi takdirde onu öldürenin cezalandırılmasının bir anlamı olmazdı. ${ }^{88}$ ez-Zemahşerî de Bağdat ekolünün görüşünü savunarak insanın tutum ve davranışlarına göre ömrünün uzatılıp kısaltılabileceğini savunmaktadır. ${ }^{89}$ el-Buharî Mu'tezile'nin bu görüşlerini reddettiği için ecelin daha insan doğmadan yazıldığını veya Allah'ın ilminde sabık olduğunu bu tarihten önce veya sonra insanın ölmesinin mümkün olmadı̆̆ anlamında bu hadisleri serdetmiştir. Onun bu hadisleri seçmesi Mu'tezile'yi sarih olarak ret niteliğindedir.

\section{Sonuç}

Netice itibariyle el-Buharî'nin es-Sahih'indeki bazı bölümleri çeşitli bid'at fırkalarını reddetmek amacıyla yazdığı gibi, Kitâbu'l-Kader'i de Mu'tezile'nin kader anlayışını tenkit etmek amacıyla oluşturduğu ortaya çıkmaktadır. Şârihlerin kader bölümünü şerhleri esnasında yer yer bazı bab başlıklarının ve bu başlıklar içindeki ayet, hadis ve bunlara ait yorumların Kaderiyye'yi reddetmek amacıyla irad edildiğini söylemeleri bunun açık göstergesidir. Bu araştırmadan da anlaşılmaktadır ki el-Buharînnin kendine has bir kader anlayışı olmayıp, daha sonra teşekkül edecek olan Ehli Sünnet'in akaid esaslarını belirleyen Ashabu'l-Hadis'in kader anlayışını benimsemis

87 en-Nevevî, Sahîhu Muslim bi serhi'n-Nevevî, XVI, 213; el-Ubbî, ikmâlu ikmali'l-muallim, IX, 39.

88 el-Eş'arî, Makâlât, I, 321 ; Ibrahim b. Muhammed el-Beycûnî, Şerhu cevheri't-tevhîd, Daru'lKutubi'l-Ilmiyye, Beyrut, 1983, s. 162.

89 ez-Zemahşeri, el-Keşaf, Daru'l-Kutubi'l-ilmiyye, Beyrut, 1995, III, 586. 
görünmektedir. Onun kader konusunda görüşleri kendisinden sonra yaşamış olan el-Eş'arî'nin görüşleriyle de paralellik arz etmektedir. el-Buharî̀nin kader konusundaki görüşlerini şu şekilde maddeleştirebiliriz:

a) el-Buharî̀ye görè kader, Allah'ın eşyayı yaratmadan önce miktarları$\mathrm{n}$, ahvalini takdir edip bilmesi ve her şeyin Allah'ın bilgisi çerçevesinde gerçekleşmesi ve Allah'ın ilminde herhangi bir değişikliğin söz konusu olmamasıdır.

b) el-Buharînin bab başlıkları altında serdettiği hadislerde her ne kadar onlardan sâdır olsa da kulların fiilleri Allah'ın ilminde sabık olup onun takdiriyle vukua gelméktedirler. Insan fiillerini kendisi yaratmaya muktedir değildir. Allah her şeyi yarattı̆̆ dir. Ona göre Kaderiyye'nin iddia ettiği gibi, insanın kendi fiillerini yarattığı hususu doğru değildir!

c) el-Buharîye göre hayır ve şer Allah'tandır. Allah hayrı yarattığı gibi şerri de yaratmaktadır!. Mu'tezile'nin iddia ettiği Allah'ın şerri yaratmadığı hususu doğru değildir. Allah'in şerri yaratmadığını söylemek Onun gücü ve kudretine halel getiriri Allah Hayrı da şerri de yaratmaktadır.

d) el-Buharîye göre hidayet ve dalâlet Allah'tandır. Dolayısıyla el-Buharî̀ye göre sapma ve saptırma insanın iradesinde olmayı Allah'ın kudretindedir. O, Allah'ın hịdayeti ve dalâleti yaratmada tek olduğunu, Allah'ın kullar için iman ve küfürden murad ettiği şeyi iktisabına muktedir olduğunu ve bunun Mu'tezilé'nin iddia ettiği gibi kulların yaratmasıyla olmadığını savunmaktadır.

e) el-Buharî̀nin anlayışına göre ecelleri ve rızıkları Allah bilir. Bilmenin hakikati, bilinen şeyi|bulunduğu hal üzere anlamaktır. Allah Zeyd'in beşyüz tarihinde öleceğini bildiği zaman, artık onun bu tarihten önce veya sonra ölmesi imkansızdır. Bundan dolayı Allah'ın bildiği ecellerin artıp eksilmesi imkansızdır. D'olayısıyla Ehli Sünnet/Ashabu'l-Hadis mezhebine göre öldürülen kimse ecelíyle ölmüştür. Mu'tezile ise o kimsenin eceliyle ölmediğini ve ecelinin kesildiğini savunmaktadır. el-Buharî irad ettiği hadislerle Mu'tezile'nin bu anlayışını reddetmektedir. 